https://doi.org/10.15407/dopovidi2021.03.104

UDC 616.12-005.4:577.112.3:615.224

T.V. Bogdan, https://orcid.org/0000-0002-6441-1410

Bogomolets National Medical University, Kyiv

E-mail: taviza@mail.ua

\title{
Influence of bisoprolol and nebivolol on the spectrum of substituted amino acids in blood plasma of patients with stable angina
}

Presented by Academician of the NAS of Ukraine V.P. Shyrobokov

For many years, $\beta$-blockers have been used to treat patients with coronary heart disease. In patients with stable angina, the effect of $\beta$-blockers on the amino acid spectrum of blood serum has been studied. Its violation is considered as one of the pathogenetic links in the development of atherosclerosis. The study showed a more efficient action of nebivolol compared to bisoprolol on the amino acid imbalance. In patients with stable angina against the background of antianginal therapy, which included bisoprolol and nebivolol, there was a significant decrease in the total amount of amino acids, the amount of essential amino acids, and the amount of essential amino acids compared to the treatment. Against the background of the nebivolol treatment, there is a positive dynamics of sulfur-containing amino acids (methionine level was maintained, taurine level was significantly increased, cystine level was normalized), isoleucine level was normalized, which indirectly indicates cardioprotective and angiprotective effect of nebivolol.

Keywords: $\beta$-blockers, bisoprolol, nebivolol, amino acids.

$\beta$-blockers remain the basic drugs for the treatment of coronary heart disease (CHD). For many years, they have been used to treat patients with stable angina (SA), unstable angina (UA), and myocardial infarction (MI). The mechanism of antianginal action of these drugs is associated with a decrease in heart rate, myocardial contractility and a decrease in systolic blood pressure. The increase in the coronary blood flow is explained by the prolongation of the period of diastolic filling of the ventricles of heart and the decrease in vasoconstriction of the coronary arteries during exercise. $\beta$-blockers are recognized as antianginal drugs of the first choice. However, formally, there is no evidence of their beneficial effect on the survival of patients with SA. The prognostic effect of $\beta$-blockers has been proven only in patients who have suffered from MI or UA, i.e., in the implementation of secondary prevention of acute coronary syndrome. One of the reasons for extrapolating these data to the recommendations for primary prevention was the proven

Ци т у в ан н я: Bogdan T.V. Influence of bisoprolol and nebivolol on the spectrum of substituted amino acids in blood plasma of patients with stable angina. Допов. Наи. акад. наук Укр. 2021. № 3. С. 104-108. https://doi. org/10.15407/dopovidi2021.03.104 
Influence of bisoprolol and nebivolol on the spectrum of substituted amino acids in blood plasma of patients...

ability of $\beta$-blockers to reduce the number of episodes of painless myocardial ischemia, according to Holter ECG monitoring [1, 2].

In addition to the already known mechanisms of action of $\beta$-blockers, it is worth noting the property of nebivolol to promote the release of nitric oxide (NO), which is one of the most important mediators functionally involved in various biological processes [3-6].

In previous studies, we obtained data on the violation of the amino acid spectrum of blood plasma in patients with emergencies [7, 8]. It is advisable to study the effect of bisoprolol and nebivolol on the spectrum of plasma amino acids in patients with SA.

We examined 75 patients with emergencies aged 65 to 76 years (mean age of patients 68.2 years \pm 6.3 years). Patients were divided into two groups: I -37 persons who received cardiket, bisoprolol, atoris, enap, acetylsalicylic acid, clopidogrel; II - 38 persons whose therapy, in addition to these drugs, included L-arginine ( $100 \mathrm{ml}$ intravenously for 10 days). All groups of patients were statistically homogeneous and comparable. The study did not include patients with heart failure stage IIB and III, atrial fibrillation, comorbidities in the stage of decompensation, cancer, and diseases of the musculoskeletal system.

Serum amino acids (AA) were used as the object of the study. The method of ion exchange liquid column chromatography was used. The following AA substitutes were determined in blood serum: ornithine, taurine, aspartic acid, serine, glutamic acid, proline, glycine, alanine, cysteine, tyrosine, and glutamine. The results of the research were processed on a personal computer using the Microsoft Office software package. For the statistical processing of the obtained data, Microsoft Excel 2010 was used. The significance of the difference between the average values of the indicators of different groups was determined by the definition of Student's t-test or Pearson's test.

73 patients aged 58 to 75 years (mean age -67.2 years \pm 5.2 years) with SA were divided into two groups: During the day in basic therapy, group I (38 patients) received bisoprolol, enalapril, atorvastatin, acetylsalicylic acid, and isosorbide dinitrate, group II (35 patients) received nebivolol, enalapril, rosuvastatin, acetylsalicylic acid, and isosorbide dinitrate. Examination of patients was performed at the beginning of the treatment and after 20 days. The control group (CG) included 18 healthy people aged $49-58$ years (mean age -53.4 years \pm 4.7 years). In patients taking nebivolol, compared with patients treated with bisoprolol, the level of total AA increased significantly by $31.29 \mu \mathrm{mol} / 100 \mathrm{ml}$, the amount of nonessential AA - by $22.22 \mu \mathrm{mol} / 100 \mathrm{ml}$, the amount of irreplaceable AA - by $9.13 \mu \mathrm{mol} / 100 \mathrm{ml}$, although, in both groups of patients, these indicators remained significantly lower compared to CG. It should be noted that against the background of therapy with nebivolol did not change the level of AA with a branched side chain compared to pre-treatment, and with bisoprolol the amount of these AA decreased even more compared to CG by $31.99 \mu \mathrm{mol} / 100 \mathrm{ml}$ and with an indicator before treatment - by $9.66 \mu \mathrm{mol} / 100 \mathrm{ml}$ (Table 1).

The analysis of the results showed that, against the background of treatment in patients of both groups, there was a significant decrease in arginine levels compared to pre-treatment by 4.18 and $1.97 \mu \mathrm{mol} / 100 \mathrm{ml}$. Compared with CG, the level of AA in patients receiving bisoprolol decreased by $6.03 \mu \mathrm{mol} / 100 \mathrm{ml}$, and in patients receiving nebivolol - by $3.82 \mu \mathrm{mol} / 100 \mathrm{ml}$ (Table 2).

It is noteworthy that in patients of the two studied groups against the background of treatment significantly decreased the level of ornithine in plasma compared with pre-treatment - 
by 2.48 and $1.23 \mu \mathrm{mol} / 100 \mathrm{ml}$. Compared with $\mathrm{CG}$ in patients receiving nebivolol, ornithine levels returned to normal. It should be noted that, in patients with SA whose therapy included nebivolol, significantly increased the level of taurine in plasma compared with pre-treatment by $2.78 \mu \mathrm{mol} / 100 \mathrm{ml}$, while in patients whose therapy included bisoprolol, the level of this AA did not change significantly.

After treatment, patients receiving nebivolol, in contrast to patients receiving bisoprolol, significantly increased the plasma serine levels by $3.0 \mu \mathrm{mol} / 100 \mathrm{ml}$, glutamic acid - by $2.49 \mu \mathrm{mol} / 100 \mathrm{ml}$. Significantly, in patients with SA receiving bisoprolol and nebivolol, the level of cysteine in the blood plasma was significantly reduced compared to treatment - by 3.4 and $3.2 \mu \mathrm{mol} / 100 \mathrm{ml}$. But in patients receiving nebivolol, the level of this AA compared with CG was normalized.

Table 1. The effect of bisoprolol and nebivolol on the amino acid spectrum of blood plasma in patients with $S A, \mu \mathrm{mol} / 100 \mathrm{ml}(M \pm m)$

\begin{tabular}{|c|c|c|c|c|}
\hline \multirow{2}{*}{ Indicator } & \multirow{2}{*}{$\mathrm{CG}(n=8)$} & \multirow{2}{*}{$\begin{array}{l}\text { Before treatment } \\
\quad(n=73)\end{array}$} & \multicolumn{2}{|c|}{ On treatment } \\
\hline & & & $\begin{array}{c}\text { Bisoprolol } \\
(n=38)\end{array}$ & $\begin{array}{l}\text { Nebivolol } \\
(n=35)\end{array}$ \\
\hline General amount of AA & $352.45 \pm 10.40$ & $236.6 \pm 6.7$ & $172.11 \pm 7.50^{* \# \&}$ & $203.4 \pm 5.3^{* \#}$ \\
\hline Nonessential AA & $275.96 \pm 8.80$ & $152.62 \pm 6.50$ & $110.04 \pm 5.60^{* \# \&}$ & $132.26 \pm 5.80^{* \#}$ \\
\hline Sulfur-containing AA & $19.43 \pm 2.10$ & $14.37 \pm 0.90$ & $10.44 \pm 1.20^{* \#}$ & $13.19 \pm 1.30^{*}$ \\
\hline AA with a branched chain & $50.62 \pm 3.50$ & $28.28 \pm 1.60$ & $18.63 \pm 1.50^{* \# \&}$ & $24.33 \pm 2.30^{*}$ \\
\hline
\end{tabular}

"Significant difference in relation to the control group. ${ }^{*}$ Significant difference in terms of indicators for treatment. ${ }^{\&}$ A significant difference between groups of patients.

Table 2. The effect of bisoprolol and nebivolol on the spectrum of replacement amino acids in the blood plasma of patients with $S A, \mu \mathrm{mol} / 100 \mathrm{ml}(M \pm m)$

\begin{tabular}{|l|c|c|c|c|}
\hline \multirow{2}{*}{\multicolumn{1}{c|}{ Indicator }} & & & \multicolumn{2}{|c|}{ On treatment } \\
\cline { 3 - 4 } & CG $(n=18)$ & $\begin{array}{c}\text { Before treatment } \\
(n=73)\end{array}$ & $\begin{array}{c}\text { Bisoprolol } \\
(n=38)\end{array}$ & $\begin{array}{c}\text { Nebivolol } \\
(n=35)\end{array}$ \\
\cline { 3 - 5 } & & & $12.61 \pm 1.30^{*}$ & $13.86 \pm 1.10^{\#}$ \\
Ornithine & $14.36 \pm 1.20$ & $15.09 \pm 1.10$ & $3.88 \pm 0.07^{\#}$ & $6.22 \pm 0.09^{* \# \&}$ \\
Taurine & $9.02 \pm 0.44$ & $3.44 \pm 0.06$ & $2.61 \pm 0.05$ & $2.84 \pm 0.07$ \\
Aspartic acid & $2.12 \pm 0.06$ & $2.79 \pm 0.05$ & $11.89 \pm 0.60^{\#}$ & $14.5 \pm 0.5^{* \# \&}$ \\
Serin & $18.75 \pm 1.43$ & $11.5 \pm 0.9$ & $13.53 \pm 0.70^{\#}$ & $14.74 \pm 0.60^{* \#}$ \\
Glutamic acid & $22.64 \pm 1.16$ & $12.25 \pm 0.08$ & $9.11 \pm 0.75^{\#}$ & $10.67 \pm 0.64^{*}$ \\
Proline & $21.42 \pm 1.27$ & $10.94 \pm 0.09$ & $20.48 \pm 1.55^{* \#}$ & $21.65 \pm 0.43^{* \#}$ \\
Glycine & $31.84 \pm 2.24$ & $26.58 \pm 0.70$ & $31.01 \pm 1.24^{* \#}$ & $32.13 \pm 1.33^{* \#}$ \\
Alanine & $46.53 \pm 1.31$ & $42.78 \pm 1.30$ & $4.92 \pm 0.05^{*}$ & $5.12 \pm 0.06^{\#}$ \\
Cysteine & $6.82 \pm 0.31$ & $8.32 \pm 0.06$ & $4.35 \pm 0.09^{* \#}$ & $5.67 \pm 0.09^{\# \&}$ \\
Tyrosine & $6.32 \pm 0.08$ & $6.72 \pm 0.07$ & $4.58 \pm 0.05^{* \#}$ & $4.86 \pm 0.05^{\#}$ \\
Glutamine & $51.89 \pm 2.45$ & $12.21 \pm 0.70$ & & \\
\hline
\end{tabular}

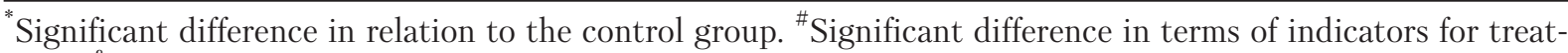
ment. ${ }^{\&}$ A significant difference between groups of patients. 
The level of tyrosine in patients receiving bisoprolol was significantly reduced compared with CG by $1.97 \mu \mathrm{mol} / 100 \mathrm{ml}$, and with the pre-treatment index by $2.37 \mu \mathrm{mol} / 100 \mathrm{ml}$. In patients treated with nebivolol, the tyrosine levels did not change significantly from CG and pre-treatment. Significantly, patients in both groups significantly decreased plasma ammonia levels after treatment - by 6.37 and $15.77 \mu \mathrm{mol} / 100 \mathrm{ml}$, respectively. Against the background of nebivolom treatment revealed a more significant decrease in plasma ammonia, which, of course, is a positive factor in this category of patients.

\section{Conclusions.}

1. In patients with SS against the background of antianginal therapy, which included bisoprolol and nebivolol, there was a significant decrease in the total amount of AA, the amount of nonessential AA and the amount of essential AA compared with pre-treatment and CG, however, in patients receiving nebivolol, the catabolism occurs slower, as evidenced by a significant difference between these indicators between the two groups of patients after treatment.

2. Against the background of nebivolol treatment, there is a positive dynamics of sulfur-containing AA levels: methionine levels were maintained, taurine levels were significantly increased, and cystine levels were normalized, which indirectly indicates the cardioprotective and antiprotective effects of nebivolol.

3. Against the background of antianginal therapy with nebivolol, there is significantly less use of arginine than in patients receiving bisoporolol, which indicates the activation of compensation processes.

4. Nebivolol normalized the level of isoleucine, which is a part of the tricarboxylic acid cycle and promotes mitochondrial biogenesis in myocardium and other muscles, preventing the oxidative stress.

5. In patients with SA receiving antianginal therapy with the inclusion of nebivolol, against the background of the normalization of ornithine, a significant decrease in the ammonia levels was observed compared with those in patients receiving bisoprolol.

\section{REFERENCES}

1. Vinereanu, D., Gherghinescu, C., Ciobanu, A. O., Magda, S., Niculescu, N., Dulgheru, R., Dragoi, R., Lautaru, A., Cinteza, M. \& Fraser, A. G. (2011). Reversal of subclinical left ventricular dysfunction by antihypertensive treatment: a prospective trial of nebivolol against metoprolol. J. Hypertens., 29, No. 4, pp. 809-817. https://doi. org/10.1097/HJH.0b013e3283442f37

2. Waehre, T., Halvorsen, B.,. Damås, J. K., Yndestad, A., Brosstad, F., Gullestad, L., Kjekshus, J., Frøland, S. S. \& Aukrust, P. (2002). Inflammatory imbalance between IL-10 and TNFalpha in unstable angina potential plaque stabilizing effects of IL-10. Eur. J. Clin. Invest., 32, pp. 803-810. https://doi.org/10.1046/j.1365-2362. 2002.01069.x

3. Girin, V. V. (2009). Assessment of the pathological condition in type 1 diabetes by determining the fatty acid spectrum of salivary lipids. Nauk. visnyk Nats. med. un-tu im. O.O. Bohomoltsia, No. 2/3, pp. 93-96 (in Ukrainian).

4. Lutai, M. I., Bugayenko, V. V., Moiseyenko, O. I., Mushtenko, L. O. \& Slobodskyi, V. A. (2011). The value of L-arginine in the treatment of patients with cardiovascular pathology. Ukr. cardiol. zhurn., No. 4, p. 96-107 (in Ukrainian).

5. Athyros, V. G., Kakafika, A. I., Tziomalos, K., Karagiannis, A. \& Mikhailidis, D. P. (2009). Pleiotropic eff ects of statins - clinical evidence. Curr. Pharm. Des., 15, No. 5, pp. 479-489. https://doi. org/10.2174/ 138161209787315729 
6. Li, Y., Arnold, J. M. O., Pampillo, M., Babwah, A. V. \& Peng, T. (2009). Taurine prevents cardiomyocyte death by inhibiting NADPH oxidase-mediated calpain activation. Free Radic. Biol. Med., 46, No. 1, pp. 51-61. https://doi.org/10.1016/j.freeradbiomed.2008.09.025

7. Lyzogub, V. G., Zavalskaya, T. V., Bogdan, V. V. \& Zhornichenko, D. M. (2015). Blood plasma nonessential aminoacids of stable and unstable stenocardia patients. Dopov. Nac. akad. nauk Ukr., No. 6, pp. 167-174 (in Ukrainian). https://doi.org/10.15407/dopovidi2015.06.167

8. Zavalska, T. V. (2015). Blood plasma essential aminoacids of stable and unstable stenocardia patients. Dopov. Nac. akad. nauk Ukr., No. 5, pp. 173-177 (in Ukrainian). https://doi.org/10.15407/dopovidi2015.05.173

Received 01.01.2021

T.В. Богдан, https://orcid.org/0000-0002-6441-1410

Національний медичний університет ім. О.О. Богомольця, Київ

E-mail: taviza@mail.ua

ВПЛИВ БІСОПРОЛОЛУ ТА НЕБІВОЛОЛУ

НА СПЕКТР ЗАМІННИХ АМІНОКИСЛОТ ПЛАЗМИ КРОВІ

У ХВОРИХ НА СТАБІЛЬНУ СТЕНОКАРДІЮ

Впродовж багатьох років $\beta$-адреноблокатори застосовують для лікування хворих на ішемічну хворобу серця. У хворих на стабільну стенокардію вивчено вплив $\beta$-адреноблокаторів на амінокислотний спектр сироватки крові, порушення якого розглядається як одна з патогенетичних ланок розвитку атеросклерозу. Встановлено ефективніший вплив небівололу порівняно з бісопрололом на дисбаланс амінокислот. У хворих на стабільну стенокардію на фоні антиангінальної терапії, що включала бісопролол і небіволол, відмічено достовірне зменшення загальної суми амінокислот, суми замінних амінокислот та суми незамінних амінокислот порівняно з показниками до лікування. На фоні лікування небівололом спастерігалася позитивна динаміка рівня сірковмісних амінокислот (утримався рівень метіоніну, достовірно збільшився рівень таурину, нормалізувався рівень цистеїну), нормалізувався рівень ізолейцину, що опосередковано свідчить про кардіопротекторну та ангіпротекторну дію небівололу.

Ключові слова: $\beta$-адреноблокатори, бісопролол, небіволол, амінокислоти. 